\title{
Niektoré paradoxy ústavnoprávneho vývoja strednej Európy v medzivojnovom období
}

\author{
Ivan Halász
}

Národná univerzita pre verejnú službu, Fakulta štátovedy a medzinárodných vzt'ahov Spoločenskovedné výskumné centrum - Ústav právnych vied (ELKH TK JTI), Budapešt' Kontaktni e-mail: halasz.ivan@tk.hu

Several Paradoxes of the Constitutional Development in the Central Europe in the Interwar Period

\begin{abstract}
:
The paper deals with the constitutional development of the Central European countries in the interwar period. It focuses on Austria, Czechoslovakia, Hungary and Poland. With exception of Hungary every country adopted new constitution in 1920/1921. Hungary, which had traditionally non-written (organic) constitution, officially returned to the prewar and prerevolutionary constitutional system. The Hungarian parliament regulated in the Act I. from 1920 only the position of the provisional head of state (Miklós Horthy), because the country was monarchy without king. This act served also as small provisional constitution. The paper focuses on the four main issues: 1. the constitution making in early period, 2 . the role of first women in parliaments, 3 . the position of the head of state in the political system, and 4. electoral systems in Central Europe. Sometimes the political development produced interesting and non-traditional situations. E.g., the most democratic constitution was adopted in Czechoslovakia by non-elected parliament. This country preserved its democratic system in the interwar period with the help of very disciplined and corrupt parties. The authoritarian tendencies were strong in Hungarian Kingdom, but the original position of provisional head of state was relatively weak in the first decade of period. The Austrian constitution designed by Hans Kelsen did not protect the democracy in Austria. Very democratic Polish constitution changed many times in the interwar period and the trend of amendments was always authoritarian.
\end{abstract}

Key words: constitution; continuity; electoral law; parliament; Central Europe

Kl’účové slová: ústava; kontinuita; volebné právo; parlament; stredná Európa

DOI: $10.14712 / 2464689 X .2021 .5$ 
Stredná Európa prešla po roku 1918 zásadnou štátoprávnou, spoločensko-politickou a čiastočne i kultúrno-mentálnou prestavbou. Jej súčast’ou boli prirodzene aj ústavnoprávne zmeny, ktoré sa prejavili predovšetkým prijatím nových ústav v rokoch 1919 až 1921. Región medzi Nemeckom a bývalým Ruskom (neskôr Sovietskym zväzom) prešiel vo vel'mi dynamickom a komplikovanom 20. storočí minimálne troma vlnami ústavodarných procesov. Každá z nich nasledovala po jednom vel'kom (globálnom) konflikte. Prvá vlna demokratických ústav prišla po prvej svetovej vojne, druhá vlna nasledovala po druhej svetovej vojne a tretiu vlnu umožnil koniec studenej vojny, pád komunistických režimov a s ním spojený rozpad Sovietskeho zväzu. ${ }^{1}$ Každá vlna mala svoje charakteristické vlastnosti a špecifické problémy. Nasledujúce riadky však budú tematicky venované len prvej $\mathrm{z}$ nich.

Rok 1918 so sebou nepriniesol len rozpad starých stredo- a východoeurópskych monarchií (Rakúsko-Uhorsko, cárske Rusko, Osmanská ríša, čiastočne cisárske Nemecko) a vznik nových národných štátov, ale aj prvú vel'kú vlnu republikanizmu a skutočne radikálny pokus demokratizovat’ región. Väčšina nových štátov vznikla ako republika (Československo, Estónsko, Fínsko, Litva, Lotyšsko, Pol'sko a Rakúska republika). Nové ústavy však dostali aj zväčšené monarchie (Král'ovstvo Srbov, Chorvátov a Slovincov, t.j. neskoršia Juhoslávia a Rumunsko). Napriek tomu, že kontrarevolučné Mad'arsko admirála Miklósa Horthyho urobilo všetko preto, aby sa vymedzilo voči revolučnému vývoju medzi októbrom 1918 a letom 1919, ani tu už nebolo možné ignorovat' všetky zmeny a trendy. Skoro všade bolo zavedené demokratické volebné právo, ktoré sa vzt'ahovalo aj na ženy. Prirodzene s výnimkou Fínska, kde ženy mali volebné právo už aj pred rokom 1918. S rozličnou intenzitou sa začali prejavovat' taktiež sociálno-reformistické snaženia, ktorých ciel'om bolo neutralizovat' nebezpečenstvo nekontrolovaného revolučného výbuchu a nástupu bol'ševizmu. ${ }^{2}$

\section{Zrod nových ústav a charakter ústavodarných orgánov}

Skoro všetky spomínané tendencie sa prejavili v nových ústavách, ktoré však okrem výnimiek neboli schopné garantovat' demokratický vývoj regiónu až do konca medzivojnového dvadsat'ročia. Väčšina ústav prijatých po prvej svetovej vojne v časoch revolučnej hrozby bola totiž demokratickejšia než skutočné spoločenské a kultúrno-mentálne pomery. Prirodzene ani celková zaostalost' a z nej prameniaca ekonomická nestabilita regiónu neprospeli jeho demokratizácii. ${ }^{3}$ Jedinou krajinou medzivojnovej strednej a východnej Európy, ktorá si až do roku 1938 zachovala funkčný občiansko-demokratický politický systém, bola prvá Republika československá. V ostatných štátoch regiónu od polovice 20. rokov 20. storočia postupne dochádzalo k nastoleniu rozličných foriem autoritatívnych režimov. Výnimkou nebolo ani blízke Rakúsko, kde pôvodnú demokratickú ústavu pomáhal koncipovat’ jeden z najvýznamnejších právnikov 20. storočia Hans Kelsen.

\footnotetext{
1 TRÓCSÁNYI, L. Alkotmányozás és rendszerváltás Közép- és Kelet-Európában. Jogtudományi Közlöny, 1995, 8. sz. (augusztus), s. 384-390.

2 SÁRI, J. Közép-Európa alkotmányai 1994: a tagadás tagadása. Jogtudományi Közlöny, 1994, július-augusztus, s. 275.

3 Problematiku medzivojnovej sociálnej, ekonomickej a politickej disharmónie v regióne, ktorá zabránila jeho demokratizácii podrobne spracoval BEREND, T. I. Válságos évtizedek. Budapest: Magvető, 1987.
} 
Pritom prvorepublikové Československo bolo jedinou krajinou vtedajšej užšie chápanej strednej Európy, ktorej ústavu neprijal slobodne zvolený povojnový parlament, ale dočasný revolučný orgán, ktorý sa dokonca pôvodne aj nazýval Revolučným (resp. dočasným) národným zhromaždením. Vznikol postupným rozšírením Národného výboru, ${ }^{4}$ ktorý realizoval prevzatie moci koncom októbra 1918. Pôvodne si v ňom české politické strany rozdelili miesta podl'a politických pomerov v zastupitel'ských orgánoch z obdobia Rakúsko-Uhorska. ${ }^{5}$ Slovenský klub vznikol kooptovaním poslancov koncom roku 1918, avšak okrem Slovákov v ňom zasadali aj viacerí českí predstavitelia (okrem iných aj Alice Masaryková a Edvard Beneš). ${ }^{6}$ Predstavitelia početných neslovanských menšín v tomto zbore nezasadali. ${ }^{7}$ To do určitej miery spochybnilo jeho legitimitu, čo neskôr zdôrazňovali predovšetkým nemeckí menšinoví politici, ako aj dobová mad'arská odborná spisba venovaná československému vývoju. ${ }^{8}$

Určitý nedostatok formálnej legitimity československého ústavodarného procesu kompenzoval široký - skoro až celonárodný - konsenzus českých a slovenských politických strán počas prípravy a prijímania novej ústavy. Konsenzus sa hl'adal napriek tomu, že socialisticko-agrárnická koalícia mala dostatočnú väčšinu na prijatie ústavy, avšak vyvarovala sa jednostranných krokov. Ferdinand Peroutka vtedajšiu situáciu zhrnul nasledovne: „Přrevrat byl proveden koalicí všech československých stran; mělo se za nezbytné, aby také ústava, toto dokončení převratu, byla provedena touž celonárodní koalicí a aby se tak stala nezávislou na vůli Němců, dychtivě - a jak se vědělo - rozhořčeně čekajících přede dveřmi Národního shromáždění. Všichni předvídali prudkou ofenzivu Němců, jakmile vstoupí do ústavního života, a chtěli proti ní být zabezpečeni národní jednomyslností aspoň ve věcech základních. Uznávalo se dále, že revoluční sněmovna nevyšla z voleb a nemůže se proto honosit tím, že přesně vyjadřuje mocenské rozvrstvení v národě: je opatrnější vzhledem $\mathrm{k}$ budoucnosti, jestliže ve sboru takto vzniklém, kde stranám byla propůjčena síla jen podle názorů Národního výboru z r. 1918, žádná strana nebude znásilněna, nebot' kdyby pak volby ukázaly, že byla úsudkem Národního výboru podceněna, oč jiného by usilovala tak horlivě jako o revizi ústavy jí vnucené? Byla proto tedy ústava vytvořena tak, aby mohla trvat beze změny, i kdyby v koloběhu střídavého politického štěstí ty strany, které r. 1920 byly navrchu, se ocitly jednou dole. Bylo výslovně ujednáno mezi stranami, že zákony ústavní a a k nim připojené zákony jiné, volební, jazykový, župní, budou tak udělány, aby strana, která s nimi nemůže souhlasit, mohla je aspoň snášet (tolerari posse). "9 Úplný

4 O jeho vzniku pozri RYCHLíK, J. Rozpad Rakousko-Uherska a vznik Československa. Praha: Vyšehrad, 2018, s. 224-226.

$5 \quad$ PAVLÍČEK V. a kol. Ústavni právo a státověda. II. dill. Ústavni právo České republiky. 1. úplné vydání. Praha: Leges, 2011, s. 33.

6 KRAJČOVIČOVÁ, N. Úloha a význam Klubu slovenských poslancov v parlamentnom systéme ČSR v rokoch 1918-1920. In: FERENČUHOVÁ, B. - ROGULOVÁ, J. a kol. Občianska spoločnost' a politická kultúra: kapitoly z dejin Slovenska 1918-1938. Bratislava: Historický ústav SAV, 2012, s. 34.

7 PETRÁŠ, R. Menšiny v meziválečném Československu. Praha: Univerzita Karlova, Nakladatelství Karolinum, 2009, s. 171. Budovania nového československého štátu sa na druhej strane aktívne zúčastnili predstavitelia židovskej komunity. PAVLÍČEK V. K počátkům a hodnotám československé ústavnosti. In: PAVLÍČEK V. O české státnosti. 1. Český stát a Němci. Praha: Karolinum, 2002, s. 150.

8 ZSEDÉNYI, B. A csehszlovák alkotmány létrejöttének előzményei. Ideiglenes és végleges alkotmány. Kisebbségi jogok. Nemzetgyülés. Miskolci Jogászélet, 1925, 6. sz., s. 47-48.

9 PEROUTKA, F. Budováni státu III. Praha: LN, 1991, s. 924-925. 
konsenzus sa síce stranám dosiahnut’ nepodarilo, ale nakoniec väčšina strán za novú ústavu zahlasovala. Zo 155 čiastkových hlasovaní sa v 105 prípadoch podarilo hlasovat' spoločne (podl’a Peroutku svorne), „... ostatní byla bojovná, možno-li ovšem nazvat bojem událost, v níž výsledek byl předem dobře znám. V ústavním výboru se nepodařilo sjednat úplnou dohodu; národní demokracie přenesla boj do pléna, podavši řadu pozměňovacích návrhů. Poněvadž nebyly přijaty, hlasovala pak proti různým partiím jazykového zákona, proti vázaným kandidátním listinám, proti tomu, že volební právo do senátu začíná už od šestadvaceti let. Lidová strana, získána odstraněním odluky církve od státu, hlasovala pro vše mimo jazykový zákon. Slovenská l’udová strana, podřízujíc se disciplíně Slovenského klubu, hlasovala s koalicí. Dr. Kramář, utrpěv porážku při boji o jazykový zákon, okázale odešel ze zasedací síně."10

Samostatnú Rakúsku republiku s dnes už nezvyčajným názvom (Republik Deutschösterreich, t. j. Nemecko-rakúska republika) vyhlásilo dočasné - jednokomorové - Národné zhromaždenie pozostávajúce $\mathrm{z}$ nemeckých poslancov bývalej Ríšskej rady (Reichsrat) 12. novembra 1918. ${ }^{11}$ Prvé povojnové slobodné a demokratické vol'by sa však konali už vo februári 1919 a ich vít’azom boli sociálni demokrati, ktorí potom dohodli vel'kú koalíciu s druhou dominantnou silou, ktorú predstavovala krest’ansko-sociálna strana (predchodcovia dnešných l’udovcov). Táto koalícia 1. októbra 1920 prijala rakúsku demokratickú ústavu, ktorá je po mnohých zmenách a s určitými prestávkami v platnosti vlastne až dodnes. Na jej vypracovaní sa zásadným spôsobom podiel’al už spomínaný významný právny vedec Hans Kelsen. ${ }^{12}$ Po prijatí ústavy sa vel'ká koalícia rozpadla, konali sa nové vol’by a k moci sa dostala pravicová koalícia krest’anských sociálov, pronemeckých nacionalistov a agrárnikov. ${ }^{13}$

Konflikt medzi rakúskou pravicou a l'avicou sa neustále stupňoval a po vel'kej hospodárskej kríze viedol dokonca ku krátkej občianskej vojne a nastoleniu autoritatívneho pravicového režimu kancelára Engelberta Dollfusa. Okrem iného sa tu pravdepodobne prejavil aj fakt, že rakúska ústava síce netrpela nedostatkom formálnej - slobodnými vol'bami podporenej - legitimity, ale jej celospoločenskej legitimite predsa len nepomohol fakt, že sa zrodila v dôsledku prehratej prvej svetovej vojny. ${ }^{14}$ Inak to bol taktiež aj problém nemeckej demokratickej ústavy prijatej v roku 1919 vo Weimare, ktorá mala vel’ký vplyv na neskorší rakúsky ústavný vývoj. ${ }^{15}$ Prirodzene rakúsky ústavný vývoj urobil v strednej

10 Tamže, s. 927-928.

11 O tomto období pozri podrobnejšie WIEDERIN, E. Von der Staatsgründüng 1918 zur Bundesverfassung 1920. In: BUSSJÄGER, P. - OBERDANNER, J. (eds.). 3. November 1918 - Die Länder und der neue Staat. Beiträge zur Festveranstaltung , 100 Jahre selbständiges Land Voralberg”. Hamburg: NAP - New Academic Press, 2019, s. 141-155.

12 NÉMETH, I. Az osztrák út. Grotius, 2012, 49 sz., s. 5 a s. 21. [online]. Dostupné na: http://www.grotius .hu/doc/pub/EFNLUG/2012_47_nemeth_grotius_e-konyvtar_49.pdf. [cit. 26. 11. 2020].

13 Sociálni demokrati mali 62 mandátov v Národnej rade, boli teda na druhom mieste po l'udovcoch s ich 79 mandátmi. Tamže, s. 21.

14 JAKAB, A. Das Österreichische Bundes-Verfassungsgesetz (1920) und die Weimarer Reichsverfassung (1919). Weimars negativer Einfluss auf die Österreichische Verfassung. Revista de Historia Constitucional, 2019, No. 20. s. 436.

15 Tamže, s. 435-448. 
Európe do určitej miery osobitým aj fakt, že Rakúska republika vznikla ako spolkový (federatívny) štát. ${ }^{16}$

Pol'skú ústavu z roku 1921 prijal ústavodarný Sejm zvolený začiatkom roku 1919 na základe volebného nariadenia dočasnej hlavy práve sa rodiaceho pol'ského štátu. Novodobý zakladatel' štátu Józef Piłsudski týmto nariadením zaviedol v Pol'sku demokratické volebné právo, ktoré sa vzt’ahovalo aj na ženy. Koncom januára bol zvolený jednokomorový ústavodarný Sejm (1919-1922), ktorý nepokrýval ešte všetky územia vznikajúceho Pol’ska, lebo zvrchovaná moc jeho orgánov sa ešte neuplatňovala všade. Preto bol Sejm neskôr ešte niekol'kokrát doplnený. Pomery v ňom sa však už zásadne nemenili - 394 mandátov si v Sejme viac-menej rovnomerne rozdelili nacionalistická pravica, centrum a l'avica. Národnostné menšiny boli taktiež prítomné v parlamente - 11 mandátov mala židovská menšina a 2 mandáty nemecká národná skupina. ${ }^{17}$ Pôvodne sa počítalo so zvolením 526 poslancov, nakoniec však v zbore v roku 1921 zasadalo len 423 zástupcov l’udu. ${ }^{18}$

Zasadat' začal Sejm - hoci v neúplnom zložení - už 10. februára 1919, t. j. necelé tri mesiace po vzniku druhej Pol'skej republiky, ktorá bola pritom v ešte t’ažšej situácii než susedné Československo. Tomuto faktu (t. j. rýchlemu otvoreniu Sejmu) sa pripisoval vel'ký význam, lebo ako poznamenal vtedajší významný politik a potom predseda parlamentu Maciej Rataj „... existuje Pol’sko, máme Sejm...“19 Priamo zvolený Sejm mal teda zohrat' dôležitú úlohu v procese budovania štátu a jeho legitimácie v očiach domáceho obyvatel'stva aj zahraničia. Nakoniec tento zbor prijal po dlhých diskusiách a zložitých kompromisoch novú pol'skú demokratickú ústavu, na ktorej príprave sa zúčastnili najprestížnejší pol'skí odborníci a mnohé autority vtedajšieho verejného života. Vel'a sa diskutovalo o postavení prezidenta republiky - stúpenci amerického modelu chceli silného, stúpenci vtedajšieho francúzskeho modelu reprezentatívneho prezidenta. Paradoxne silného prezidenta odmietali skôr predstavitelia pravice, ktorá bola pritom v mnohých otázkach menej demokratická ako centrum a l’avica, lebo sa obávali, že by sa ním stal ich úhlavný nepriatel' - Józef Piłsudski. ${ }^{20}$ Ten nakoniec skutočne nechcel zaujat' takýto post, ktorý v oslabenej podobe nevyhovoval jeho naturelu a úlohám budovania štátu, ktoré generál presne videl pred sebou. Výkonná moc bola teda rozdelená medzi nepriamo voleného prezidenta a premiéra, zákonodarná moc - taktiež podl’a francúzskeho vzoru - medzi Sejm a Senát. Spolu tvorili Národné zhromaždenie.

Dokonca ešte aj v Mad’arsku prebehli začiatkom roku 1920 vol’by do Národného zhromaždenia, ktoré vyhrali malorol'níci a krest’ansko-národné sily zamerané na strednostavovského mestského voliča. Na jednej strane prebehli síce v atmosfére doznievajúceho bieleho teroru z jesene roku 1919 a mad’arská sociálna-demokracia z nich bola fakticky vylúčená, na druhej strane sa však konali na základe demokratického volebného nariadenia

16 WIEDERIN, op. cit., s. 155.

17 KOVÁCS, I. Pitsudski... Katyň... Solidarita. Klíčové pojmy polských dějin 20. století. Praha: Barrister \&Principal, 2010, s. 48.

18 BARDACH, J. et kol. Dzieje Sejmiu Polskiego. Warszawa: Wydawnictwo Sejmowe, 2011, s. 138. V roku 1919 34,2 \% poslancov patrilo k pravici, 30,8 \% k stredu (tvorili ho Pol'ská l'udová strana „Piast”, krest’anská demokracia a Národný robotnícky zväz) a 30,3 \% k l'avici (Pol'ská socialistická strana a Pol'ská l'udová strana „Wyzwolenie”).

19 Tamže, s. 139.

20 KOVÁCS, op. cit., s. 74. Pozri aj BARDACH et kol., op. cit., s. 148-150. 
kontrarevolučnej vlády pravicového továrnika Istvána Friedricha, ktorý sa predtým politicky angažoval v časoch občiansko-demokratickej revolúcie koncom roku 1918. ${ }^{21}$

V auguste 1919 patril Friedrich však už medzi kontrarevolučných politikov, ktorí chceli zvrhnút' len niekol'ko dní existujúcu odborársko-sociálno-demokratickú vládu Gyulu Peidla, čo sa im nakoniec 6-7. augusta aj podarilo. Svoju legitimitu sa snažili odvodit' od poverenia z rúk arcivojvodu Jozefa Augustína Habsburg-Lotharingen, ${ }^{22}$ ktorého posledný cisár a král' Karol IV. ešte predtým, ako sa vzdal výkonu svojej král’ovskej moci, vymenoval za tzv. král'ovho človeka v Uhorsku. Táto funkcia mala latinský názov homo regius. V podstate išlo o král'ovského miestodržitel'a. 7. augusta 1919 sa sám Jozef prehlásil za vládcu (kormányzó), v tejto pozícii však nevydržal dlho a musel sa vzdat'. Inak Jozef z poverenia král'a Karola vymenoval počas astrovej revolúcie bezprostredne po vojnovej porážke grófa Mihálya Károlyiho za ministerského predsedu, takže s menovaním krátkodobých premiérov mal už svoje skúsenosti. Vo vyhláške z 8. augusta sa inak doslova v jeho prípade hovorilo o král'ovskom kniežati, resp. vojvodovi (királyi herceg). ${ }^{23}$

Možnosti kontrarevolučnej pravicovej vlády, ktorá prevzala kontrolu nad budapeštianskymi ministerstvami, však boli vel'mi obmedzené. Zásadným faktom bola okupácia hlavného mesta rumunskými vojskami, ktorá trvala až do 14. novembra 1920. Dohodové vel'moci taktiež nepovažovali takúto vratkú vládu za ideálne riešenie, čiastočne aj preto, že v nej chýbali pravicoví sociálni demokrati. Slabá Friedrichova vláda teda nezískala ich uznanie. ${ }^{24}$ Západní diplomati intenzívne hl'adali riešenie, ktoré by bolo funkčné a aspoň čiastočne demokratické. Hlavnú úlohu v ňom mal zohrat' velitel' malej kontrarevolučnej Národnej armády admirál Miklós Horthy, ktorý bol sympatický predovšetkým Britom, ako aj obnova činnosti parlamentu. Horthy bol však vtedy skôr stúpencom otvorenej vojenskej diktatúry. Západná diplomacia musela teda uzmierit’ tieto protichodné sily a tendencie - potrebu obnovit' parlamentarizmus, nastolit' právny poriadok hoci aj s pomocou sily a zároveň nájst' silného vodcu, ktorý by dokázal garantovat' stabilitu systému. Potrebovali k tomu preto politicky reprezentatívnejšiu „občiansku“ vládu, ktorú zostavil krest’anský politik Károly Huszár po odchode Rumunov z Budapešti 24. novembra 1919.25

Pre potreby zvolania konsolidačného Národného zhromaždenie ešte Friedrichova dočasná vláda prijala už spomínané volebné nariadenie, ktoré bolo primerane duchu doby (a neprimerane vtedajším mad'arským pomerom) vel'mi demokratické. Nariadenie bolo publikované ešte 17. novembra. Volebné právo získali všetci muži starší ako 24 rokov, ktorí boli aspoň 5 rokov štátnymi občanmi. V prípade žien sa vyžadovalo aspoň šest'ročné občianstvo a schopnost' čítat' a písat' po mad'arsky. V oboch prípadoch bol potrebný aspoň polročný pobyt v danom mieste. Muži, ktorí strávili aspoň 12 mesiacov na fronte, získali volebné právo aj vtedy, ak ešte nemali 24 rokov. Pasívne volebné právo sa viazalo na vek 30 rokov. $^{26}$

21 MÁTHÉ G. (ed.). A választójog. Budapest: Press Publica, 2002, s. 35-36.

22 Jozef August Habsburg-Lotharingen (1872-1962) bol pravnukom Leopolda II. a pochádzal z uhorskej vetvy Habsburgovcov. Jeho otec, podobne ako predtým starý otec, bol uhorským palatínom.

23 KARDOS, J. A Szent Korona-tan és a legitimizmus. Budapest: Gondolat, 2012, s. 65, pozn. 118.

24 GRATZ, G. A forradalmak kora. Budapest: Magyar Szemle Társaság, 1935, s. 240-241, a s. 248.

25 Tamže, s. 248-251.

26 Tamže, s. 261, a MÁTHÉ, op. cit., s. 35-36. 
Vol'by do Národného zhromaždenie sa konali 25.-26. januára 1920 a skončili sa vít’azstvom dvoch relatívne nových politických síl - malorol’níckej strany na vidieku a Krest’ansko-národného zjednotenia v mestách. Spolu s menšími krest’anskými stranami získal krest’ansko-národný tábor 77 mandátov. Malorol’níci dostali 71 mandátov. Medzi týmito hlavnými silami sa nachádzali menšie krest’ansko-malorol'nícke zoskupenia so 7 mandátmi, ako aj 6 poslancov národných demokratov, ktorí zastupovali predovšetkým mestských liberálnych voličov. 3 poslanci sa nezaradili. V novom zákonodarnom zbore nemal teda nikto jednoznačnú väčšinu, preto bolo nad'alej potrebné vládnut' koaličným spôsobom. Okrem toho išlo o menší zastupitel'ský zbor, než aké zasadali v Budapešti pred prvou svetovou vojnou. Namiesto 451 poslancov v parlamente zasadalo len 164 poslancov, a potom, ako sa konali vol'by aj na území za riekou Tisou, t. j. na východe krajiny, ktorý dlhší čas okupovalo Rumunsko, stále mal ešte len 207 poslancov. ${ }^{27}$

Tento zbor však už bol vhodný pre ústavnoprávnu konsolidáciu situácie a nového krest’ansko-národného režimu. Celý proces sa vo vtedajšom politickom jazyku nazýval obnovením ústavnosti, a to na základe tzv. historickej (t. j. nechartálnej a organickej) ústavy spred októbra 1918. Základnou právnou normou tohto konsolidačného procesu bol zákonný článok I. z roku 1920 o obnovení ústavnosti a dočasnom výkone funkcií hlavy štátu. Svojim spôsobom išlo o malú ústavu, ktorou sa začalo medzivojnové verejnoprávne provizórium. Zákon vyhlásil Národné zhromaždenie za jediného predstavitel'a národnej suverenity, zrušil platnost' a účinnost' právnych noriem prijatých počas občiansko-demokratickej, ako aj radikálnej socialistickej revolúcie a pokúsil sa pokračovat’ tam, kde Mad'arsko bolo pred vyhlásením republiky v novembri 1918. Zároveň sa pokúsil vyriešit’ tie otázky, ktoré sa nedali riešit' s pomocou návratu k starým právnym normám. Vzt'ahy s bývalou rakúskou čast'ou monarchie boli totiž už prerušené a na uhorskom tróne už nesedel panovník z roku Habsburgovcov. Ich návrat si neželala predovšetkým Dohoda a susedia z Malej dohody, ale netúžili po nich ani mnohí mad’arskí nacionalisti. Preto zákon na dočasný výkon funkcie hlavy štátu vytvoril post vládcu, resp. dočasného správcu krajiny (kormányzó). ${ }^{28}$

Národné zhromaždenie do tejto novej funkcie zvolilo 1. marca admirála Miklósa Horthyho, ktorý sa takto zmieril s ideou parlamentarizmu a viac nepresadzoval vojenskú diktatúru. ${ }^{29}$ Inak myšlienka parlamentarizmu mala vtedy silné pozície v mad'arskom národne orientovanom verejnoprávnom myslení. Osobitne silne v ňom žili spomienky na reformné snemy z prvej polovice 19. storočia, ako aj vplyvný snem z obdobia rakúsko-uhorského dualizmu. ${ }^{30}$

Na záver tejto úvodnej časti treba poznamenat' ešte jeden dôležitý fakt. Všetky stredoeurópske ústavy prechádzali v medzivojnovom období výraznými zmenami. Ich tendencia bola jednoznačná - posilňovali sa autoritatívne prvky v rámci jednotlivých ústav a verejnoprávnych systémov. V Pol'sku dokonca v roku 1935 prijali úplne novú ústavu, ktorá zodpovedala autoritatívnym zmenám, ku ktorým došlo počas prvého desat'ročia existencie

27 Tamže, s. 273-275.

28 Po mad’arsky sa táto funckia nazývala „kormányzó”. Zastával ju (s iným obsahom) napríklad János Hunyady v 15. storočí, alebo Lajos Kossuth v roku 1849.

29 Počas hlasovania bola budova Snemu plná jeho vojakov, ktorí dokonca vošli ozbrojení aj do zasadacej siene. Niektorých poslancov a ministrov do budovy nechceli vpustit' (napríklad ministra financií baróna Korányiho). Nakoniec bol Horthy zvolený 131 hlasmi zo 141 hlasov prítomných poslancov. Tamže, s. 282. EGYED, I. A mi alkotmányunk. Budapest: Magyar Szemle, 2016, s. 238-250. 
sanačného režimu Józefa Piłsudského. Už predtým však prijímali novely ústavného textu z roku 1921 (napríklad v roku 1926, t. j. bezprostredne po štátnom prevrate). ${ }^{31}$ V Rakúsku sa ústava z roku 1920 v medzivojnovom období zmenila viackrát, a to občas aj zásadným spôsobom (1925, 1929, potom nový ústavný režim od roku 1934). ${ }^{32}$ V Mad'arsku taktiež viackrát novelizovali zákonný článok I. z roku 1920 a vždy posilňovali práve postavenie hlavy štátu. Jedinou výnimkou bolo Československo, kde dokonca počas existencie prvej republiky ani nedošlo v významnejšej novele ústavného textu. O príčinách vtedajšej československej stability však bude reč neskôr, a to v časti o politických stranách.

\section{Prvé ženy v parlamentoch}

Poprevratové parlamenty boli prvé parlamentné zastupitel'ské zbory v histórii stredoeurópskeho regiónu, na činnosti ktorých participovali aj ženy. To zároveň znamená, že sa zúčastnili aj na príprave prvých demokratických ústav. Ich reálna úloha však ešte nebola vel'ká. V rakúskej časti monarchie mali ženy pred rokom 1918 na ríšskej úrovni volebné právo len v rámci vel'kostatkárskej volebnej kúrie. Všeobecné volebné právo sa na ne ešte nevzt'ahovalo. Jedinou ženou, ktorá bola pred rokom 1918 zvolená do českého zemského snemu, bola v roku 1912 spisovatel'ka Božena Viková-Kunětická, ktorej však Miestodržitel'stvo Král'ovstva Českého odmietlo potvrdit' poslanecký mandát vzhl'adom k tomu, že sa jednalo o ženu a ponechalo konečné rozhodnutie na českom zemskom sneme, ktorý však vtedy už nezasadal. V Revolučnom národnom zhromaždení (RNZ) od 14. novembra 1918 už zasadalo 8 poslankýn̆, ktoré delegovali rozličné politické strany. Boženu Ecksteinovú a Františku Kolaříkovú do RNS delegovali sociálni demokrati, Annu Chlebounovú a Ludmilu Zatloukalovú-Coufalovú agrárnici, Boženu Vikovú-Kunětickú Česká štátoprávna demokracia, Františku Zeminovú a Luisu Landovú-Štychovú Česká strana sociálna. Posledne menovaná po roku 1925 zastupovala už komunistov. Politicky nezaradená dcéra prvého prezidenta republiky Alice Masaryková taktiež zasadala v RNZ, kde sedela v Slovenskom klube. ${ }^{33}$

V republikánskom Rakúsku sa do parlamentu dostali prvé ženy vo vol'bách začiatkom roku 1919. Väčšinou išlo o kandidátky sociálnej demokracie a l'avice (Anna Boschek, Emmy Freundlich, Adelheid Popp, Gabrielle Proft, Therese Schlesinger, Amelie Seidel, Maria Tusch), ale jedna žena sedela aj v krest’ansko-sociálnej frakcii (Hildegard Burjan) a neskôr taktiež aj medzi tzv. Vel'konemcami (Lotte Furreg). ${ }^{34}$ Odlišná bola situácia v ústavodarnom pol'skom Sejme, kam sa poslankyne dostali cez kandidátne listiny skoro všetkých politických strán. Centristické (t. j. agrárne l'udové) a l'avicové strany zastupovali Anna Anastázia Piasecka, Franciszka Wilczkowiakowa, Irena Kosmowska, Jadwiga Dziubińska a Zofia Moraczewska. Národno-demokratickú pravicu zastupovali Gabriela

31 GARLICKI, L. Polskie prawo konstytucyjne. Wyd. 10. Warszawa: Liber, 2006, s. 11-13.

32 BRAUNEDER, W. Österreichische Verfassungsgeschichte. 11. durchgesehene Auflage. Wien: Manzsche Verlags- und Universitätsbuchhandlung. 2009, s. 209-215, a s. 234.

33 Viz: https://www.psp.cz/sqw/hp.sqw?k=1701\&z=10859.

34 Parlamentsdirektion (Hg.). Frauen im Parlament. [online]. Dostupné na: https://www.parlament.gv.at /ZUSD/PDF/Publikation_Frauen_im_Parlament_NR_BR_BF_01032019.pdf. [cit. 26. 11.2020]. 
Balicka, Maria Moczydłowska a Zofia Sokolnicka. Ich počet bol teda rovnaký ako v československom a rakúskom parlamente - v každom z nich zasadalo 8 poslankýňn. ${ }^{35}$

Na jar 1920 sa v rámci doplňovacích volieb dostala do Národného zhromaždenia aj prvá mad'arská poslankyňa v histórii. Silne katolícky orientovaná a zároveň sociálne cítiaca rodáčka z Košíc Margit Slachta tam zastupovala krest’ansko-národný tábor. Išlo o jednu z najvýraznejších žien v mad'arskej politike prvej polovice 20. storočia. Slachta, ktorá na začiatku 20. rokov v parlamente presadzovala ešte palicovanie pre osoby predražujúce svoj tovar, sa neskôr stala jednou z hlavných političiek antifašistického tábora, počas druhej svetovej vojny pomáhala prenasledovaným židom a nakoniec bola jedinou poslankyňou povojnového Dočasného národného zhromaždenia, ktorá primerane svojmu monarchistickému presvedčeniu začiatkom roku 1946 odvážne hlasovala proti vyhláseniu Mad’arskej republiky. Zomrela v americkej emigrácii. Slachta sa však nezúčastnila hlasovania o zákonnom článku číslo I. z roku 1920, lebo vtedy ešte nebola zvolená za poslankyňu. Do Národného zhromaždenia sa totiž dostala počas doplňujúcich volieb. ${ }^{36}$

\section{Hlava štátu a stabilita politického systému}

Po prvej svetovej vojne a následnej revolučnej vlne sa skoro v celom stredoeurópskom regióne presadilo republikánske zriadenie. Jedinú výnimku predstavovalo ultrakonzervatívne, ale v zásade parlamentné Mad’arsko, ktoré bolo až do krachu v rokoch 1944/1945 „král'ovstvom bez král’a“. Právne presadzovaný návrat - hoci aj neúplný - k verejnoprávnym pomerom spred októbra 1918 mal v Mad’arsku jednak slúžit' konsolidácii konzervatívno-národného režimu admirála Horthyho, a jednak mal symbolizovat' revizionistické snahy politickej elity krajiny. Zároveň však bolo jasné, že úplná reštaurácia predrevolučných politických a sociálnych pomerov nie je možná.

Dokonca aj zloženie Národného zhromaždenia zo začiatku roku 1920 napriek jeho krest'ansko-konzervatívnej a národnej terminológii a pátosu signalizovalo značný posun vplyvu od latifundistickej aristokracie a vel'kopodnikatel'ských skupín k strednostavovským podnikatel'ským, statkárskym, úradníckym a dôstojníckym vrstvám. Tieto vrstvy však boli podstatne antisemitskejšie a nacionalistickejšie, ako liberálno-konzervatívna spoločenská a politická elita spred roku 1918. Svoju úlohu tu prirodzene zohral šok z vojnovej porážky a trauma z revolúcie. Svojim spôsobom aj admirál Horthy bol predstavitel’om práve týchto vrstiev.

Konzervatívny premiér gróf István Bethlen (1921-1931) s pomocou rozličných politických manipulácií, administratívnych presunov a konzervatívneho okresania volebného práva dokázal síce v záujme tradičných elít spomalit’ proces nástupu nových kádrov a taktiež aj požadovanú „,výmenu stráží“ v rámci elitných vrstiev, ale zabránit’ mu nedokázal. Paradoxne bol to práve on, kto uzavrel kompromis so sociálnymi demokratmi, ktorých vtedajšia národno-krest’anská verejnost' považovala za nenárodných a deštruktívnych. Umožnil im politickú sebarealizáciu v rámci Budapešti a znovu reštauroval niektoré ustanovenia

35 Inak v medzivojnovom Pol'sku najviac žien poslankýň a senátorik mal tradične tábor generála Piłsudského, potom národní demokrati, l’udovci, socialisti a dokonca aj ukrajinská a židovská menšina. Po jednej zástupkyni v Sejme mali svojho času aj národní krest’ania a komunisti.

36 MOLNÁRNÉ BALÁZS, A. A köztársaság ellenzéke: Slachta Margit érvelése a Nemzetgyűlésben az 1946. évi I. törvénycikk kapcsán. Acta Humana, 2017, 5. évf., 1. sz., s. 39-50. 
liberálneho štátu, hoci aj nie v takej širokej podobe ako pred vojnou. V každom prípade však zabránil pokračovaniu bieleho teroru a oddialil nástup fašizmu.

Postavenie hlavy štátu bolo v prvom desat'ročí existencie verejnoprávneho provizória napriek konzervatívnemu a deklarovanému monarchistickému dizajnu, ako aj autoritatívnym tendenciám, podstatne slabšie, než bolo predtým postavenie panovníka. V mnohých ohl'adoch sa blížilo skôr k postaveniu prezidenta v poloprezidentskej republike. Konkrétne verejnoprávne postavenie dočasnej hlavy mad'arského štátu bolo skutočne špecifické. Zvolilo ho spomedzi štátnych občanov Národné zhromaždenie tajným hlasovaním bez uvedenia časového limitu na dočasný výkon funkcie hlavy štátu alebo presnejšie povedané dovtedy, kým sa s konečnou platnost'ou nevyrieši otázka výkonu tejto funkcie. Hoci správca, resp. vládca krajiny prevzal podl'a zákona vo všeobecnosti král'ovské úlohy a kompetencie, niektoré dôležité - pre ústavnú monarchiu typické - práva nezískal. Nemohol napríklad odročit' zasadnutie parlamentu, zostalo mu len pomerne obmedzené právo suspenzívneho veta, všetky jeho akty boli viazané na kontrasignáciu a výkonnú moc mohol realizovat' len cez parlamentu zodpovedné ministerstvo, t. j. cez vládu. Vyhlasovat' vojnu a uzatvárat' mier mohol taktiež len so súhlasom parlamentu. Nemal ani právo udel'ovat' šl'achtické tituly. Protestant Horthy stratil aj dôležité práva, ktoré mali predtým katolícki Habsburgovci ohl'adne katolíckej cirkvi. Na zodpovednost' ho mohol zobrat' v prípade porušenia ústavy a zákonov len parlament, pred ktorým musel po svojom zvolení zložit' prísahu. Všeobecnú amnestiu bolo možné vyhlásit’ len zákonom. Zákonný článok I. z roku 1920 nič nehovoril o zastupovaní vládcu krajiny. Na druhej strane si Horthy v tejto pozícii zachoval vel'mi dôležité prerogatíva smerom k armáde, ktorá predstavovala základ jeho moci. V jej rámci mal totiž obrovskú prestíž.

Zaujímavá bola aj otázka zodpovednosti dočasnej hlavy štátu. Podl’a 14. paragrafu zákonného článku I. z roku 1920 bola osoba hlavy štátu nedotknutel'ná a mala takú istú trestnoprávnu ochranu ako predtým osoba král'a. V prípade porušenia ústavy alebo zákona však mohlo Národné zhromaždenie správcu - na rozdiel od král'a - vziat' na zodpovednost'. Zákon tu nešpecifikoval, o aké porušenie zákona by tu išlo. Iniciatívu týmto smerom muselo preukázat' minimálne sto poslancov, avšak k hlasovaniu o braní na zodpovednost' boli potrebné dve tretiny všetkých poslancov. Celú procedúru mal upravit' a konkretizovat’ špeciálny zákon, ktorý však nebol prijatý. Neskôr v roku 1937 zákonným článkom číslo XIX. úplne zrušili možnost' parlamentnej zodpovednosti správcu. Podl'a vtedajšej argumentácie takto chceli posilnit' Horthyho autoritu smerom k zahraničiu aj dovnútra krajiny. Spomínalo sa aj odpútanie od vplyvu politických strán, ktorý však ani predtým nebol v jeho prípade silný. ${ }^{37}$

Toto „nemonarchické“ postavenie hlavy štátu si všimol aj významný medzivojnový rakúsky ústavný právnik Adolf Merkl, ktorý v jednom zo svojich odborných článkov nazval ironicky Mad'arsko „král'ovskou republikou,“ resp. „,rojalisticky podfarbenou aristokratickou republikou.“38 Viedenský univerzitný profesor však nielen ironizoval, ale svoj názor podložil aj argumentami. Vychádzal z toho, že dôležitá nie je sebadefinícia režimu, ale reálna konštrukcia moci a postavenie jej jednotlivých zložiek. Podl'a jeho

37 SZABÓ, I. A kormányzó jogállása (1920-1944). Publicationes Universitati Miskolciensis. Sectio Juridica et Politica, 1996, 12, s. 152-153.

38 MERKL, A. A mai Magyarország államformájának kérdéséről. Jogtudományi Közlöny, 1925, 60. évf., 5. sz., s. 35 . 
názoru zákonný článok I. z roku 1920 vlastne do konečného vyriešenia otázky štátnej formy zaviedol skôr republikánske zriadenie, v ktorom sa hlava štátu volí, čiže svoj post nezastáva z vlastnej sily, ale z vôle l'udu, ktorú vyjadroval parlament. Z tohto pohl'adu je vcelku irelevantný názov funkcie, ako aj to, že zákon neurčil dížku mandátu hlavy štátu. Nehovorí však nič o tom, že poverenie dočasnej hlavy štátu je doživotné. Okrem toho vládca krajiny je síce hlavou štátu, ale nepanuje. ${ }^{39}$ Merkl mal skeptický názor aj o celej koncepcii právnej kontinuity s obdobím pred októbrom 1918, ktorý určite prerušil dovtedajšiu kontinuitu. Podl'a jeho názoru nie je možné úplne ignorovat' štátoprávny vývoj od pádu monarchie v dôsledku vojnovej porážky a následnej revolúcie - zmenou štátneho zriadenia sa totiž v Mad'arsku trikrát zmenila identita štátu a po monarchii nasledovali tri republiky: demokratická, bol'ševická a napokon už spomínaná rojalisticko-aristokratická. ${ }^{40}$ Väčšina medzivojnových mad’arských ústavných právnikov s Merklom nesúhlasila, ale jeho názor uverejnili a potom s ním pomerne intenzívne diskutovali. ${ }^{41}$

Inak samotný zákonný článok I. z roku 1920 skutočne nehovoril nič o štátnej forme, hoci zo symbolického obnovenia predrevolučných právnych pomerov a z názvu štátu tento fakt viac-menej vyplýval. Situáciu vyjasnilo až jedno nariadenie vlády z toho istého roku (2394/1920. ME), ktoré predpísalo, že všetky štátne orgány, úrady a inštitúcie majú používat' prídavné meno „mad’arský král'ovský“. Súdy však až do roku 1930 prijímali rozhodnutia v mene mad’arského štátu, potom v mene Svätej koruny.

V roku 1921 došlo po druhom pokuse o návrat posledného král'a Karola k jeho oficiálnej detronizácii. Zákonný článok XLVII. z roku 1921 však jednoznačne deklaroval, že „,národ zachováva starobylú inštitúciu král'ovstva bez zmeny, ale obsadenie král'ovského stolca odloží na neskoršie obdobie“. Inak Horthy od roku 1920 až do roku 1944 používal hlavné rezidencie predchádzajúcej král'ovskej dynastie na území Mad’arska - býval aj úradoval na Budínskom král’ovskom zámku - a v lete používal ako štátnu rezidenciu reprezentatívny kaštiel' v mestečku Gödöllő.

Postavenie a právomoci dočasnej hlavy štátu však nezodpovedali vtedy bežnému monarchistickému zriadeniu - na toto vlastne narážal už citovaný Adolf Merkl. Aj niektorí vtedajší významní mad’arskí ústavní právnici upozorňovali na nesúlad medzi oficiálnou monarchiou a konkrétnym modelom výkonu funkcie hlavy štátu, ako aj na to, že ak občania dlho nebudú vidiet' skutočného král'a, tak zistia, že sa dá existovat' aj bez neho. ${ }^{42}$ Čiastočne aj preto sa snažili v duchu vtedajšieho archaizujúceho a ultrakonzervatívneho národného diškurzu posilnit’ kult svätoštefanskej Svätej koruny. ${ }^{43}$

Reálny mad'arský model pripomínal republikánske zriadenie osobitne v 20. rokoch, ked' bol skoro celé jedno desat'ročie premiérom politicky vel'mi talentovaný gróf István Bethlen. Krajinu a konzervatívny politický systém konsolidujúci Bethlen vedel dobre spolupracovat's Horthym, ktorý sa vtedy čiastočne stiahol z každodennej politiky. Postupne sa však aj jeho politická a právna pozícia začala posilňovat'. Už v auguste 1920 napríklad zákonný článok XVII. z roku 1920 dal Horthymu široké možnosti rozpustit' parlament

\footnotetext{
39 Tamže, s. 34.

40 Tamže, s. 34-35.

41 O tom pozri SCHWEITZER, G. A „magyar királyi köztársaságtól” a Magyar Köztársaságig: az 1946. évi

I. törvénycikk visszhangja a korabeli közjogi irodalomban. Acta Humana, 2017, 5. évf., 1. sz., s. $27-38$.

42 GÁBOR, G. A kormányzói méltóság a magyar alkotmányban. Budapest: Athenaeum, 1933, s. 204.

43 CSEKEY, I. A kormányzí jogkör kiterjesztése. Magyar Szemle, 1937, č. I.
} 
a umožnil mu udel'ovat' milost'. Od prijatia zákona XXII. z roku 1926 o hornej komore mohol Horthy výrazne ovplyvňovat’ aj jej zloženie. Nasledujúce významné rozšírenie jeho právomocí realizoval zákonný článok XXIII. z roku 1933, ked’ Horthy získal už neobmedzené právo rozpustit’ a odročit' parlament. Zákonný článok XIX. z roku 1937 posilnil jeho právo veta, ako aj obmedzil možnosti zobratia na zodpovednost'. Získal aj právo navrhnút' svojho nástupcu. Zákonný článok II. z roku 1942 zase vytvoril funkciu jeho zástupcu, ktorým sa stal Horthyho syn István. István Horthy však v skutočnosti nemal možnost' vykonávat' túto funkciu, lebo čoskoro zomrel počas leteckej havárie. ${ }^{44}$

Napriek tomu, že medzivojnové Mad'arsko bolo silne pravicovou krajinou, kde tvrde prenasledovali ilegálnych komunistov a len vlažne tolerovali demokratickú l'avicu, posilnenie postavenia hlavy štátu Horthyho nebolo motivované predovšetkým komunistickou revolučnou hrozbou, ale skôr nebezpečenstvom zo strany radikálnej pravice. Nacionalistická a antisemitská krajná pravica bola totiž v krajine silná už na začiatku 20. rokov, potom bola jej hrozba čiastočne eliminovaná už spomínaným premiérom Bethlenom, nakoniec však začala nezadržatel'ne silniet' po vel'kej ekonomickej kríze.

Prirodzene tento trend súvisel aj s medzinárodným vývojom a objavením sa Adolfa Hitlera v Nemecku. Najväčšie vít’azstvo dosiahla krajná pravica počas prvých skutočne tajných parlamentných volieb v roku 1939, ked' získala skoro pätinu všetkých odovzdaných hlasov. ${ }^{45}$ Nie náhodou sa vtedy zmenila aj funkcia Svätej koruny a verejnoprávnej náuky o nej. Dovtedy táto oprášená a trocha archaická koncepcia suverenity (pôvodne stavovského) l'udu slúžila predovšetkým obnoveniu ústavnosti v krajine, d'alej legitimácii „král'ovstva bez král'a“ a čiastočne aj revizionistickým ciel’om. V 30. rokoch sa ju však už mnohí právnici snažili využit’ na spomalenie prenikania vtedy moderných (t. j. totalitných fašistických a nacistických) myšlienok do mad’arského verejného práva a politického usporiadania. ${ }^{46}$

Symbolickým hlavným medzivojnovým protipólom archaizujúceho a zvláštneho mad’arského ústavného modelu bolo republikánske Československo na čele s prezidentom Tomášom G. Masarykom. Hoci československá ústavná listina z roku 1920 v mnohých štrukturálnych aspektoch vychádzala - podobne ako pol'ská ústava z roku 1921 - z francúzskeho republikánskeho vzoru, postavenie dvoma komorami Národného zhromaždenia zvoleného prvého prezidenta republiky bolo výnimočné. Nevzt'ahovalo sa na neho obmedzenie, podl'a ktorého prezident mohol zastávat' túto funkciu len dve po sebe nasledujúce sedemročné volebné obdobie a opätovne by mohol byt' zvolený až po tom, ako uplynulo sedem rokov od ukončenia jeho druhého mandátu. Masaryk bol za prezidenta zvolený štyrikrát $(1918,1920,1927,1934)$. Okrem toho v súlade s princípom kontinuity moci zostával predchádzajúci prezident vo funkcii az do zvolenia nového prezidenta. V prípade nemožnosti výkonu funkcie viac ako šest' mesiacov mohol parlament zvolit' námestníka prezidenta. Hoci nemal právo navrhnút' svojho nástupcu, prezident Masaryk tak urobil počas svojej abdikácie v Lánoch v roku 1935.

44 FÖGLEIN G. - MEZEY B. - RÉVÉSZ T. M. Az államfö. In: MEZEY, B. (ed.). Magyar alkotmánytörténet. Budapest: Osiris, 2003, s. 366-369.

45 MÁTHÉ, op. cit., s. 41-42.

46 KARDOS, op. cit., s. 182-190, a SCHWEITZER, G. Közjogi provizórium, jogfolytonosság, új közjogi irány Az 1919/1920-1944 közötti magyarországi alkotmányjog-tudomány vázlata. Közjogi Szemle, 2014, 1. sz., s. $8-17$. 
Právo udel'ovat' milost' československých medzivojnových prezidentov bola širšia, ako v prípade dočasnej hlavy štátu Mad'arského král'ovstva. Dokonca aj jeho trestoprávna imunita bola v prvom medzivojnovom desat'ročí širšia - zodpovedal totiž len za špeciálne upravenú velezradu, a nie za porušenie ústavy a zákonov. Za tú dôsledne preberali zodpovednost' svojou kontrasignáciou ministri. ${ }^{47}$ Inak pomerne intenzívne polemiky sa viedli o tom, či prezident nemá zodpovednost' alebo je len nestíhatel'ný. ${ }^{48} \mathrm{~V}$ prvom prípade by jeho konanie voči nemu bolo vylúčené aj v období po ukončení mandátu, resp. výkonu funkcie. ${ }^{49}$ Inak nestíhatel'nost' zvoleného kandidáta začínala už jeho zvolením a nie zložením sl’ubu. ${ }^{50}$ Zároveň v zmysle obyčajného zákona parlamentom žalovaný prezident už nemohol vykonávat' svoje právomoci, čo bolo sporné z hl'adiska právnej sily obmedzujúcej normy. ${ }^{51}$

Akty prezidenta Československej republiky boli síce viazané na kontrasignáciu a všeobecnú kompetenciu vo sfére vládnej a výkonnej moci mala vláda zodpovedná parlamentu, ${ }^{52}$ reálne postavenie medzivojnových československých prezidentov bolo podstatne silnejšie. ${ }^{53}$ Súviselo to jednak s vel'kou autoritou prezidenta-zakladatel'a štátu, d'alej s pomerne fragmentovaným straníckym systémom prvej republiky, ktorý potreboval stabilizátora, a čiastočne aj s určitými monarchistickými tradíciami, ktoré Československo zdedilo po Rakúsko-Uhorsku. Inak podl'a prameňov citovaných Evou Broklovou „,monarchistickejšie“" správanie od Masaryka očakávali dokonca aj strojcovia októbrového prevratu a pražskí otcovia československej samostatnosti (Jiří Stříbrný a Antonín Švehla): „Nezdála se nám tato skromnost. Hovořili jsme o ní a rozhodli se se Švehlou při první př́ležitosti upozorniti na to prezidenta. Stalo se. Švehla mu dokazoval, že ted', kdy zbořili jsme císařský trůn, je třeba lidu dát rovnocennou náhradu. S pojmem hlavy státu že se nesrovnává taková skromnost. Naopak on je povinen svému postavení, aby všude vystupoval sebevědomě. Žádná pohádka. Prezident že musí vystupovati jako skutečný osvoboditel. Byla v tom jistá nevděčnost, když později - prezident si tuto radu vzal k srdci - po celý život se jí ŕídil a my mu ji nakonec vytýkali.“"54

Hoci sa dôsledný republikán Masaryk, ktorý vždy prikladal vel’ký význam politickému vzdelávaniu občanov, stal jedným z hlavných symbolov československého republikaniz$\mathrm{mu}, \mathrm{v}$ procese budovania svojho kultu sa vedel v mnohom opierat' o rakúske tradície stelesňované predtým postavou cisára Františka Jozefa. Na tomto fakte - podobne ako v oblasti verejnej správy - vel'a nezmenili heslá o potrebe odrakúštenia celého verejného života. Prezident republiky býval na Pražskom král'ovskom hrade, mal tri regionálne letné sídla (v Čechách, na Morave a na Slovensku), disponoval vlastnou prezidentskou štandartou, čestnou strážou, v krajine sa oslavovali jeho narodeniny a podobne. ${ }^{55}$

47 PAVLÍČEK, op. cit., s. 817.

48 PEŠKA, Z. K problému trestní odpovědnosti hlavy státu v Československu. Moderni stát, 1935, s. 230-232.

49 KOUDELKA, Z. Prezident republiky. 2. vyd. Praha: Leges, 2018, s. 281-282.

50 PEŠKA, op. cit., s. 232.

51 SOBOTA, E. - VOREL, J. - KŘOVÁK, R. - SCHENK, A. Československý prezident republiky. Praha: 1934, s. 79, a KOUDELKA, op. cit., s. 288.

52 Prezident mal teda taxatívne vymenované kompetencie.

53 O tejto téme pozri komplexne SOBOTA - VOREL - KŘOVÁK - SCHENK, op. cit.

54 BROKLOVÁ, E. Antonín Švehla. Tvưrce politického systému. Praha: Academia, 2017, s. 130. Autorka sa odvolávala na STŘíBRNÝ, J. TGM a 28. ř́jen. Praha: Tempo, 1938, s. 37.

55 KOUDELKA, op. cit., s. 339-341. 
Zvláštna situácia sa vyvinula v medzivojnovom Pol'sku, ktoré sa tiež definovalo ako dôsledná republika. Prvou hlavou štátu bol bývalý politik Pol'skej socialistickej strany a jej ilegálneho ozbrojeného krídla generál Piłsudski, ktorý s pomocou ozbrojených síl (légií) pomohol založit' a stabilizovat' obnovený samostatný pol'ský štát v jeho vel'mi t'ažkých prvých mesiacoch. Nemal však ešte titul prezidenta republiky, ale nazýval sa náčelníkom, prípadne šéfom štátu. Po prijatí demokratickej pol'skej ústavy, ktorá nedala prezidentovi široké právomoci, sa rozhodol, že nebude kandidovat' na tento post. Národné zhromaždenie hlasmi l'avice, rol'níckych l’udovcov a predstavitel'ov národnostných menšín proti kandidátovi nacionalistickej pravice zvolilo za prvého prezidenta druhej Pol'skej republiky uznávaného vodohospodára a ministra zahraničných vecí Gabriela Narutowicza, ktorý mal blízko k Piłsudskému. Pravica a nacionalisti však voči nemu vyvolávali vášne a už 16. decembra 1922, teda niekol'ko dní po zvolení, ho zavraždil nacionalistický maliar Eligiusz Niewiadomski. Atentát šokoval generála, ktorý to národnej pravici nikdy nezabudol. Národná demokracia neskôr vybudovala popravenému atentátnikovi „,vlastenecký“ kult. ${ }^{56}$ O niekol'ko dní však parlament zvolil nového prezidenta, bývalého socialistu a neskôr l'udovca Stanisława Wojciechowského, ktorý zastával túto funkciu až do štátneho prevratu v máji 1926, ked’ moc prevzal znovu generál Piłsudski a začalo sa budovanie tzv. „sanačného režimu“. 57

Napriek tomu, že Národné zhromaždenie jednoznačnou väčšinou ${ }^{58}$ zvolilo 31. mája 1926 Piłsudského za nového prezidenta, generál neprijal túto funkciu. Vol’ba však do určitej miery legitimizovala jeho štátny prevrat. Sám navrhol nového kandidáta na prezidenta, a to Ignacy Moścického, ktorý bol prezidentom až do konca medzivojnového obdobia. Poslanci ho zvolili za prezidenta 1. júna 1926. Mościcki bol univerzitným profesorom chémie - Piłsudski totiž vtedy už väčšinou veril len svojim spolubojovníkom z prvej legionárskej brigády a profesorom, resp. hospodárskym odborníkom. Politikom a politickým stranám nedôveroval a chcel ich silné pozície eliminovat' aj v zákonodarnom zbore. ${ }^{59}$ Tomu slúžili reformy, ktoré v rámci sanačného režimu postupne realizovali v desat'ročí medzi rokmi 1926 až 1935 . Celý proces dokončilo prijatie novej - viac-menej autoritatívnej - ústavy v roku 1935. Na jej základe sa však Piłsudski nevedel stat’ prezidentom, lebo čoskoro po jej prijatí zomrel.

Medzi postavením pol'ského prezidenta v ústavách z roku 1921 a 1935 boli značné rozdiely. V prvej demokratickej ústave bola táto otázka upravená v tretej časti venovanej výkonnej moci. Hned' po prezidentovi nasledovali teda ustanovenie o vláde. Podobne ako v Československu aj pol'ského prezidenta volilo Národné zhromaždenie na sedem rokov. Každý prezidentov úradný akt musel byt' kontrasignovaný. Vládu vykonával cez ministrov, ktorí však mali zodpovednost' pred Sejmom. Premier kontrasignoval dokonca aj nominácie do prezidentovej civilnej kancelárie. Prezident bol hlavným velitel’om ozbrojených síl, ale počas vojny nemohol vykonávat' svoju vedúcu funkciu nad armádou. Vtedy totiž na návrh vlády musel vymenovat' hlavného velitel'a armády. Pred špeciálnym Tribunálom štátu sa

\footnotetext{
56 KOVÁCS, op. cit., s. 76-77.

57 Tamže, s. 76-78.

58 Do parlamentu prišlo 546 poslancov, platné hlasy odovzdalo 485 poslancov, z ktorých generál dostal 292

hlasov a jeho protikandidát 193 hlasov. Tamže, s. 81 .

59 Tamže, s. 78-79.
} 
zodpovedal na návrh poslancov Sejmu za zradu, porušenie ústavy a trestné činy. Prísahu skladal pred Národným zhromaždením, ktoré ho zvolilo. ${ }^{60}$

Postavenie prezidenta vychádzalo z francúzskeho vzoru, ale zároveň nebolo až také slabé, ako sa často hovorilo. Tento post v medzivojnovom Pol'sku však nikdy nezastávala silná politická osobnost' typu Horthyho, Masaryka alebo Piłsudského, ktorí vtlačili - každý po svojom - svojmu štátu silnú pečat'. Piłsudski, ktorého občas odborná literatúra nazýva aj „demokratickým diktátorom“ lavírujúcim medzi dvoma totalitnými vel’mocami, ${ }^{61}$ od konca roku 1922 nezastával najvyššiu pozíciu v štáte, ktorý pomáhal založit'. Okrem rokov 1923 až 1926 si však vždy zachoval rozhodujúcu pozíciu v armáde. Počas sanačného režimu vládol prostredníctvom komisárov-plukovníkov, ktorí boli zväčša jeho bývalí spolubojovníci z légií, ako aj s pomocou nezávislých odborníkov.

V medzivojnovej pol'skej armáde vystriedal generál a neskôr maršal viacero pozícií od náčelníka generálneho štábu, cez predsedu úzkej vojenskej rady až po ministra obrany. V kritickom roku 1930 sa na určitý čas stal dokonca aj premiérom - práve vtedy, ked' ním vytvorený režim pritvrdil politiku voči opozícii. Piłsudski sa totiž tradične nebál zodpovednosti. Vtedy sa voči jeho režimu totiž dostali do opozície tie centristické a l'avicové strany, ktoré ho pred niekol'kými rokmi ešte podporovali. Ich vedúcich politikov a mnohých aktivistov sanačný režim pozatváral. Premiér, ktorý chcel vidiet' na čele štátu efektívnu a pevnú vládu so stabilnou podporou v Sejme, už nechcel tolerovat' opozičnú väčšinu v parlamente. Jeho postoj zhrnul mad’arský odborník na jeho život István Kovács nasledovne: „Piłsudski nechtěl dosáhnout této změny politického kurzu zavedením otevřené diktatury a likvidací systému demokratických institucí, jak to očekávali mnozí z jeho př́vrženců, nýbrž vznikem takového parlamentu, ve kterém by vládní většina byla jistá a neotřesitelná. $\mathrm{K}$ tomu - kromě podmínky platnosti dosavadního volebního zákona - musel v každém př́padě vyhrát volby. Jelikož to pro Piłsudského byla existenční otázka, bez jakéhokoliv zaváhání nechal zadržet všechny ty, kteří ohrožovali úspěch jeho plánu.“662

Posuny v jeho myslení o úlohe a organizácii štátu dobre vyjadrili ustanovenia novej pol'skej ústavy z roku 1935. Tá už vo svojej úvodnej kapitole podriadila nielen vládu, ale aj obe komory parlamentu, ozbrojené sily, súdnictvo a štátnu kontrolu pod zvrchovanost' prezidenta, ktorý mal za úlohu harmonizovat' činnost' všetkých vedúcich orgánov štátu. Jeho postaveniu sa venovala hned' druhá vel'ká kapitola ústavy, ktorá predchádzala kapitole o vláde, a až potom nasledovali orgány zákonodarnej moci. Prezident získal vel'mi široké právomoci a prerogatívá, medzi iným aj právo samostatne navrhnút' svojho nástupcu, počas vojny zase svojho zástupcu, d'alej menovat' a odvolat' premiéra, predsedov najvyšších súdnych orgánov, ako aj ozbrojených síl. Mal aj právo viac-menej bez obmedzenia rozpustit' Sejm a Senát a vypísat' nové vol'by do nich. Akty, ktoré pramenili z jeho prerogatív, už nepotrebovali kontrasignáciu a nebol za ne zodpovedný. Zodpovednost' hlavy štátu pred zákonodarným zborom sa vlastne z ústavného textu vytratila. Kandidáta na nového prezidenta vyberal zbor elektorov, pozostávajúci z najvyšších činitel’ov štátu a 75 elektorov spomedzi vhodných občanov, ktorých v pomere 2/3 a 1/3 volil Sejm a Senát. Zástupcom prezidenta v prípade nemožnosti výkonu funkcie sa stal predseda Senátu. Na

60 KONIECZNY, A. - KRUSZEWSKI, T. Historia administracji na ziemiach polskich. Wybŕ źródeł. [Wrocław]: Kolonia Limited, 2002, s. 377-381.

61 KOVÁCS, op. cit., s. 84.

62 Tamže, s. 84. 
tento konzervatívnejší zákonodarný orgán mal prezident tradične väčší vplyv - tretinu jeho členov totiž menoval samotný prezident a len zbytok senátorov volili občania. ${ }^{63}$

V Rakúskej republike hrala oficiálna hlava štátu obmedzenejšiu úlohu ako v Československu a Mad’arsku. Zároveň tu chýbala aj taká masívna - hoci do určitej miery neformálna - politická osobnost', akou bol Piłsudski. V prvých mesiacoch v republikánskom Rakúsku, ktoré sa snažilo správat' diskontinuitne vo vzt’ahu k predchádzajúcemu Rakúskemu cisárstvu, neexistoval inštitút prezidenta republiky a moc prechodne vykonávala Štátna rada, v ktorej boli proporčne zastúpené rozhodujúce politické sily, ako aj Štátne direktórium pozostávajúce z troch predsedov predchádzajúceho orgánu. V štátnej vláde zasadali rezortní ministri a štátni tajomníci.

Vol'by do ústavodarného Národného zhromaždenia, ktoré prijalo v roku 1920 novú ústavu, sa konali už v prvej polovici roku 1919. Post konkrétneho spolkového prezidenta, ktorého na štyri roky volili obe komory zákonodarného zboru, vytvorila až nová demokratická ústava. Prezident bol zodpovedný za hocijaké porušenie právnych noriem, jeho kompetencie boli taxatívne vymedzené a všeobecnú (alebo zostatkovú) kompetenciu mala vláda vedená spolkovým kancelárom. Prezidentské akty potrebovali kontrasignáciu. K zmenám, ktoré vychádzali predovšetkým z poloprezidentského nemeckého weimarského vzoru a značne posilnili postavenie prezidenta došlo až v roku 1929. ${ }^{64}$ Posilnili sa taktiež jeho právomoci smerom k armáde. V zmysle pôvodného textu ústavy z roku 1920 mala právo riadit' armádu (der Oberbefehl) Národná rada, od novely v roku 1929 už spolkový prezident. Inak v roku 1929 poslanci symbolicky redefinovali aj princíp suverenity l’udu vyjadrený v prvom článku ústavy: namiesto formulácie, že štátna moc pochádza z l’udu, deklarovali, že právo pramení z l'udu. ${ }^{65}$

Mandát prezidenta bol odvtedy už šest'ročný a bola zavedená jeho priama vol'ba a politická odvolatel'nost' cez referendum, podobne ako v susednom Nemecku. Posilnila sa jeho pozícia aj v oblasti politickej a právnej zodpovednosti. Inak rakúsky prezident mal pred rokom 1929 len právnu zodpovednost’ za porušenie právnych noriem. O politickej zodpovednosti ústava nehovorila. V oblasti trestného práva mal podobnú imunitu ako poslanci a o jej pozbavení rozhodovalo rozšírené Spolkové zhromaždenie. O obvinení z porušenia ústavy taktiež rozhodoval tento orgán dvojtretinovou väčšinou. Rozsudok prijímal ústavný súd, ktorý ho mohol pozbavit' funkcie a politických práv. Po roku 1929 o iniciovaní referenda o odvolaní prezidenta rozhodovalo Spolkové zhromaždenie. ${ }^{66}$

Prezidentskú funkciu v medzivojnovom období nikdy nezastávali najvplyvnejší rakúski politici. V prechodnom období rokov 1919 až 1920 bol hlavou štátu krátko sociálny demokrat Karl Seitz, potom v rokoch 1920 až 1928 - teda počas dvoch volebných období nezávislý Michael Hainisch, a od roku 1928 až do pripojenia sa k Vel'konemeckej ríši krest’anský socialista Wilhelm Miklas. Skutočne silnými osobnost’ami však v rakúskej medzivojnovej politike boli vždy iné postavy - napríklad sociálni demokrati Karl Renner a Otto Bauer na začiatku republiky, alebo už spomínaný kancelár Engelbert Dollfuss

\footnotetext{
63 KONIECZNY - GRUSZEWSKI, op. cit., s. 466-469.

64 JAKAB, op. cit., s. 437-438. Citovaný autor tento proces aj nazval čiastočnou weimarizáciou rakúskej ústavy.

65 JAKAB, op. cit., s. 438 a s. 440.

66 SZABÓ, I. Ausztria államszervezete 1918-1955. Budapest: PPKE JÁK, 2010, s. 57-58, a s. 167-170, potom s. 177-178. Taktiež pozri BRAUNEDER, op. cit., s. 219-221.
} 
v 30. rokoch 20. storočia. Renner, Dollfuss, ako aj Michael Mayr alebo Johann Schuschnigg, ktorí sa významne zapísali do rakúskej histórie, boli všetci spolkoví kancelári.

Najvýraznejšou, najspornejšou a zároveň aj najtragickejšou postavou medzi nimi bol krest’anský socialista Dollfuss, ktorý bol kancelárom od roku 1932. Dollfuss sa pokúsil kombináciou politického katolicizmu a rakúskeho fašizmu (Heimwehr-fašizmus) inšpirovaného Talianskom zachovat' rakúsku suverenitu pred nacistickým Nemeckom. Nakoniec sa stal obet'ou nacistického pokusu o štátny prevrat v roku 1934. Predtým však ešte v tom istom roku došlo pod jeho vedením v Rakúsku ku krátkej, ale otvorenej občianskej vojne medzi rozličnými odtieňmi pravice a rakúskymi socialistami. Porazení sociálni demokrati boli potom zatlačení do ilegality. ${ }^{67} \mathrm{~V}$ roku 1934 došlo aj k prijatiu novej autoritatívnej rakúskej ústavy inšpirovanej ideami politického katolicizmu, juhoeurópskeho korporativizmu a špecifického austrofašizmu. Ciel'om ústavy bolo zachovanie samostatnosti Rakúskej republiky a odvrátenie nemeckej nacistickej hrozby.

\section{Politické strany a stabilita systému}

Medzivojnové obdobie možno označit’ za vrchol systému moderných masových strán v Európe. Demokratický parlamentarizmus a ústavný poriadok si je možné len t’ažko predstavit' bez fungujúcich politických strán. Na začiatku 20. storočia mali skoro všetky stredoeurópske národy vytvorené aspoň zárodky tých politických a ideologických hnutí, ktoré potom dominovali ich vývoju v celej prvej polovici tohto tragického storočia. Bez pochopenia ich úlohy nie je možné pochopit' ani funkčnost' alebo nefunkčnost' medzivojnových politických systémov v strednej Európe.

Tradične sa v odbornej literatúre považuje za najúspešnejší štát regiónu Československo, ktoré si ako jediné zachovalo občiansko-demokratický charakter politického zriadenia až do roku 1938. Z tohto dôvodu existuje určitá tendencia idealizovat’ medzivojnovú ústavu a politický systém, ktorý z nej vychádzal. Prirodzene do úvahy sa berú aj ekonomické výsledky prvej republiky, ako aj relatívne pozitívna atmosféra v prostredí dominantného (teda českého) národa, ktorý sa považoval za vít’aza prvej svetovej vojny.

O mýtuse a realite prvej československej ústavy mal zaujímavé postrehy profesor Václav Pavlíček: „... ústava z roku 1920 byla dílem na svou dobu zdařilým ve smyslu demokratickém a právním a př́sluší jí význačné místo v meziválečné historii Evropy i proto, že jí odpovídaly faktické pořádky... byla dílem celonárodního kompromisu, nepoplatná tomu či onomu stranickému názoru a že byla stř́idmá v myšlenkovém obsahu i literárním projevu. V průběhu let její platnosti působila i neochota koaličních politických stran měnit základní zákon státu z obavy, aby tím nebyl eventuálně rozpoután kolotoč dalších změn, který by mohl ohrožovat stabilitu koaličních poměrů."“68

Pavlíček však zároveň v citovanej knihe videl aj nedostatky tejto ústavy, hoci fakt, že nebola prijatá demokraticky zvoleným orgánom až tak dramaticky nevnímal. Spomenul síce kabinetný spôsob jej vzniku, ten však bol podl'a jeho názoru realistickým riešením, zaistil odbornú úroveň textu a neoslabil jej demokratický obsah. ${ }^{69}$ Problém videl skôr v tom, že ústava ponechala viacero tzv. bielych miest a hlavne jej ustanovenia boli

\footnotetext{
67 BEREND, op. cit., s. 363-366.

68 PAVLÍČEK a kol., Ústavní právo a státověda. II. díl, s. 82.

69 Tamže, s. 69.
} 
porušené prijatím zákona o mimoriadnej moci nariad'ovacej v roku 1933, ktorý preniesol v dôležitých oblastiach zákonodarnú právomoc z parlamentu na vládu ,... a tím ohrozil samy demokratické základy vlády“ ${ }^{\text {. }}{ }^{70}$ Najpodstatnejšia pripomienka z pohl'ade tejto štúdie je však nasledovná: „Podstata faktické ústavy tkvěla totiž nikoliv v moci ústavních institucí, ale v moci politických stran, za což ústava sama nemohla (o politických stranách se ani nezmiňovala). Tato pozice politických stran jako hlavního sloupu moci se do roku 1926 projevovala konkrétně v koalici zvané „,pětkou“, což byl orgán lídrů pěti představitelů vládnoucích politických stran. Smyslem tohoto orgánu bylo zajistit v parlamentu potřebnou většinu těmto stranám a tím i stabilitu demokratického vládnutí proti extrému pravicovému či levicovému a proti odstředivým snahám německým a části reprezentace slovenské." ${ }^{71}$

Československé politické strany, ktorých korene siahali ešte do obdobia monarchie, a ktoré pomerne dobre kombinovali ideológiu a stavovské záujmy svojich voličov, skutočne zohrali stabilizujúcu úlohu v medzivojnovom politickom systéme, a to napriek tomu, že ich skorumpovanost' a klientelistické prepojenie so štátnou mocou nemožno v súčasnosti považovat' za nasledovaniahodný príklad. Celá prvá republika sa vlastne stala zajatcom vládnucich umiernených l'avicových, pravicových a centristických politických strán, ktoré si na dlhé roky rozdelili jednotlivé ministerstvá a vytvorili oligarchický systém straníckej partokracie. Na druhej strane nešlo o strany vodcovského typu, predstavovali skôr široký stred spoločnosti, vedeli uzatvárat' kompromisy a ani jedna z nich sa pred Mníchovom nestala natol'ko dominantnou, že by dokázala ostatným partnerom prerást' cez hlavu.

Eva Broklová paradox „štátotvorného“ československého straníckeho systému zhrnula nasledovne: „Současného historika až překvapuje naprostá důslednost, s níž tento stát institucionálně budoval, zvláště srovnáme-li československý politický systém se systémem německé výmarské republiky. Stručně řečeno, Československo díky Švehlovi využilo pro budování parlamentní demokracie, kterou vesměs převzaly po válce nové demokracie, existenci systému politických stran, jež byly v habsburské monarchii reprezentantkami českého národa. Ne všechny státy měly tuto možnost a jejich systémy na tom selhaly. “72 Švehla totiž budoval republiku ako ,štát strán“. Podl'a jeho kl'úča dostali strany mandáty v Národnom výbore a iných zboroch. „Švehla prosadil své názory na uspořádání moci ve státě ještě dále... Křesla tak připadla představitelům politických strán, jejichž stále rostoucí převaha byla pozorovatelná od vzniku státu... Záhy se tak projevila síla fenoménu, jakým bylo politické stranictví."73

Podl'a Peroutku stranícka disciplína, ktorá inde vo svete charakterizovala predovšetkým sociálnych demokratov, bola v Československu typická pre všetky strany. „Vytvořil se tu typ nejorganizovanější demokracie na světě a z houževnatosti, s níž tyto poměry odolávají všem kritikám, lze usuzovat na to, že nějakým způsobem odpovídají skutečným poměrům v zemi a vyhovují opravdové potřebě... Zda se tato demokracie neobává trochu sama sebe? Ve velké krizi, která ohrozila demokratické systémy v letech třicátých dvacátého století, se tato organizace, založená na stranách, osvědčila, a to mluví v její prospěch, i když námitky z oboru politické estetiky nemohou umlknout a i když bychom se sami

Tamže, s. 83.

Tamže, s. 83.

BROKLOVÁ, op. cit., s. 122.

Tamže, s. 124-126. 
některých z nich nechtěli vzdát: Československo se lépe drželo v oné protidemokratické smršti než všechny ostatní státy ve střední a východní Evropě. Nemůžeme přehlédnout, že tento úspěch byl následek toho, že skutečné a hrozivé zmatky se nedostavily a že zmatky byly zažehnány právě dohodou mezi silnými stranami. Musíme se snažit být spravedlivými k tomuto př́isnému systému stranickému, i když se někdy protiví našemu pudu k svobodě. Je jedinou skutečnou tradicí, která se vyvinula za samostatnosti, a odchýlit se od ní náhle bylo by nebezpečím: odvrat od ní musel by vyrůst opět právě tak organicky, jako vyrostla ona sama. Přehlížíme-li věci v celku, jsme puzeni říci, že systém vlády stran prokázal Československu více dobrého než zlého, i když si nezakrýváme nic ze stranické neušlechtilosti, kterou do veřejného života vnášel, a i když nezavíráme oči nad korupcí, jíž se proviňoval." ${ }^{74}$

V oblasti ústavného práva však tento systém prostredníctvom volebných reverzov a volebného súdu akiste neformálne porušil princíp slobodného mandátu. ${ }^{75}$ Otázne je, či by celý systém bez tejto poistky dokázal fungovat' a neskončil by postupným rozpadom a marginalizáciou podobne ako v Pol'sku. Ako negatívny príklad slúžilo aj medzivojnové demokratické Francúzsko. Ferdinand Peroutka to zhrnul nasledovne: „Je třeba být spravedlivým a uvést také dobré stránky existujícího stavu: opatřuje pevnou a trvalou vládu, zbavuje stát nervózy, zavádí do poměrů pořádek. Ve Francii, kde poslancům byla zachována úplná volnost, panuje kolotání a kmitání střídajících se vlád, a lepší lidé vznášejí tam žaloby právě opačné a přejí si zavedení stranické discipliny. V historické perspektivě je možno říci: vláda stran nad mandáty stačila zatím na jeden cíl: opatřit vždy státu silnou, spolehlivou vládu, která se může spolehnout na disciplínu stran a ví, co prosadí. Nestačila už na druhý cíl: zachovat při tom živost parlamentu a zajímavost jeho jednání. Je to pochopitelné tam, kde se činí větší nárok na poslancovu poslušnost než na jeho vlastní úsudek. Neváháme však vyznat, že první cíl byl daleko důležitější ve své době. Slabost vlád bývala největším zlem."76 Občas teda aj klientelistické a čiastočne skorumpované strany môžu zohrat’ stabilizujúcu úlohu. Nakoniec netreba zabudnút' ani na pozitívnu úlohu jednotlivých kooperatívnych strán v procese vzniku prvej republiky koncom roku 1918 a pri vyhnutí sa radikálnej sociálnej revolúcii v nasledujúcich mesiacoch. ${ }^{77}$

Vel'kou výhodou československých strán bolo aj to, že - čiastočne aj vd'aka „k. und k.“ rakúsko-uhorským tradíciám - nemali vo svojej činnosti zakódované násilné metódy prameniace často z predchádzajúceho ilegálneho postavenia. To bol do určitej miery problém viacerých pol'ských strán, ktoré hlavne v rámci bývalého cárskeho Ruska museli po dlhé roky pracovat' ilegálne a asi preto aj neskôr kombinovali legálnu a ilegálnu činnost'. Viaceré z nich mali - primerane ruským tradíciám - aj svoje bojovky a iné ozbrojené zložky. Z takéhoto prostredia koniec-koncov prišiel aj Piłsudski. Ilegálna činnost' predsa len zmenšuje ochotu hl'adat' kompromis a zvyšuje náchylnost' používat' násilné metódy. To sa prejavilo hlavne v prvých rokoch existencie nezávislého Pol’ska. Určité polovojenské zložky pridružené k politickým stranám sa síce objavili aj v Československu (napríklad slovenská l'udácka Rodobrana alebo česká Vlajka), ale našt’astie s výnimkou Sudetonemeckej strany sa nestali trvalou súčast'ou československého politického života.

74 PEROUTKA, op. cit., s. 929.

75 Tamže, s. 963-976.

76 Tamže, s. 975-976.

77 Tamže, s. 124. 
Podobné stranícke tradície, ako v českých krajinách mali síce aj v Rakúsku, ale tam sa politický a spoločenský život začiatkom 20. rokov vel'mi zradikalizoval, polarizoval a čiastočne aj militarizoval. Vznikli polovojenské úderky jednotlivých politických smerov, ktoré si občas vybavovali účty na uliciach. Rakúske demokratické tradície nemali ešte hlboké korene a ich posilneniu neprospelo ani to, že k pokusu vybudovat' demokratickú republiku došlo po porážke v prvej svetovej vojne. ${ }^{78} \mathrm{Tu}$ sa do určitej miery prejavil silnejší vplyv susedného Nemecka, ako aj horšia ekonomická situácia. Okrem toho trojpólová rakúska politika bola na rozdiel od fragmentovanej československej politickej palety podstatne viac polarizovaná. ${ }^{79}$ Medzi sociálnymi demokratmi, krest’anskými socialistami a nemeckými nacionalistami sa preto podstatne t'ažšie hl'adali kompromisy, hoci - ako to ukázali prvé roky existencie republiky - ani v Rakúsku neboli nemožné.

Rovnako v Pol'sku aj Rakúsku došlo časom k snahe vytvorit' vel'kú provládnu väčšinu v parlamente, a to pomocou organizovania vládnej strany zhora. O toto sa pokúsil v Rakúsku na báze krest’ansko-sociálnej strany a ozbrojeného Heimwehru Dollfuss a v Pol'sku sanačný kurz Józefa Piłsudského. Už v roku 1926 tam s pomocou štátnej správy založili Nestranícky (bezpartijný) blok na podporu vlády, ktorý v roku 1930 nakoniec vyhral vol'by, ale nie v takej miere, ako sa pôvodne očakávalo. Preto boli potrebné už spomínané vel'ké represie proti inak životaschopným a v spoločnosti zakoreneným pol'ským stranám po roku 1930. Tieto strany potom zohrali dôležitú úlohu počas vojnového protinacistického odboja, ale to je už iná téma.

S vytvorením tzv. neideologickej dominantnej vládnej strany mali pravdepodobne najstaršie skúsenosti v medzivojnovom Mad'arsku, ktoré malo v regióne asi najdlhšie parlamentné tradície, spolu s tradíciou zodpovednosti vlády pred parlamentom (od roku 1867). Kontrolnú funkciu parlamentu smerom k vláde však relativizoval fakt, že v Uhorsku a potom aj v medzivojnovom Mad'arsku existoval dominantný stranícky systém, ktorému vždy suverénne panovala vel'ká vládna strana, ktorá postupne prerastala so štátnou správou a ekonomickými elitami. Menšie strany hrali len úlohu štatistov a určitého folklórneho doplnku. Ich členovia sa dostali k moci vtedy, ked' urobili nejaký kompromis s vládnou Slobodomysel'nou stranou. Podobný stranícky systém sa pokúsil vytvorit' v pozícii premiéra sedmohradský gróf István Bethlen, ktorý nesympatizoval s krajne-pravicovými a antisemitskými radikálmi, ale aj moderná demokracia mu bola vzdialená. Konzervatívny elitista Bethlen pochopil, že v podmienkach demokratického volebného práva z roku 1919 nebude vediet' uskutočnit' svoje plány. Z tohto dôvodu v roku $1922 \mathrm{~s}$ podporou Horthyho presadil vel'kú volebnú reformu, ktorá v mnohých ohl'adoch znamenala návrat do minulosti. S pomocou zvýšenia voličských cenzov sa mu podarilo skoro o 10 až $15 \%$ zmenšit' potenciálny okruh voličov. ${ }^{80}$

Najväčšiu zmenu však znamenal návrat k otvorenému (teda verejnému) hlasovaniu na vidieku. Tajne sa mohlo volit’ len v Budapešti a vo väčších mestách. Reforma znamenala, že tajne vedela volit' približne pätina všetkých oprávnených voličov. ${ }^{81}$ Organizácia volieb bola v rukách vidieckej verejnej správy, ktorá už vedela ako postupovat'. Bethlen sa snažil opierat' o elitné vrstvy spoločnosti a pokial' možno demotivovat' a depolitizovat' nižšie

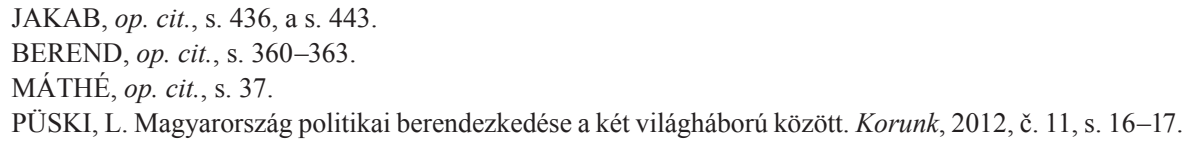


spoločenské vrstvy. ${ }^{82}$ Jeho reforma bola najprv zavedená nariadením vlády, ale v roku 1925 dostala aj zákonnú podobu. V takomto systéme sa volilo až do roku 1939, ked' sa už všade volilo tajne. Výsledkom bol vel'mi dobrý výsledok sociálne orientovanej krajnej pravice a intenzívnejšia radikalizácia spoločnosti v predvečer svetovej vojny.

Bethlen vytvoril aj novú dominantnú vládnu stranu. Pôvodne dúfal v podporu strednostavovskej a mestskej Strany krest’ansko-národneho zjednotenia, tam však bolo vtedy ešte privel'a krajnepravicových radikálov. Preto s jemu podobne zmýšl’ajúcimi konzervatívnymi politikmi vstúpil do malorol'níckej strany, ktorá sa stala základom pre budovanie novej vládnej strany. Predtým tam však musel ešte eliminovat' vplyv pôvodných, rol'nícke záujmy skutočne zastupujúcich politikov, čo sa mu manipuláciami a korupciou postupne aj podarilo. Nakoniec o tom, kto bude zastupovat' vidiek v parlamente, rozhodoval premiér a jemu podriadený štátny aparát na mieste.

Nová vládna strana sa dostala do povedomia politizujúcej verejnosti pod názvom Zjednotená strana. Išlo o dominantnú stranu, ktorá pravidelne s vel'kou prevahou vyhrávala vol'by, ale nebola to ešte moderná masová strana. Popri nej existovali sociálni demokrati, ktorí boli silní v Budapešti, neskôr opoziční nezávislí malorol’níci, menšie občianske liberálne zoskupenia a silnejúca krajná pravica. V roku 1932 sa stal premiérom krajnepravicový politik Gyula Gömbös, ktorého inšpirovali nemecké a talianske fašistické vzory. Na základe starej vládnej strany, odkial’ vytlačil konzervatívcov bethlenovského typu, sa Gömbös pokúsil vytvorit' pod menom Strana národnej jednoty modernú masovú stranu. Skorá smrt' mu zabránila realizovat' tento plán, ale vládna strana sa skutočne posunula radikálne doprava. ${ }^{83}$ Inak Horthy, ktorý mal na začiatku svojho vládnutia bližšie ku krajnej pravici, sa postupne dostával pod vplyv konzervatívneho krídla vlastného režimu, ktoré sa práve rozširovaním jeho právomocí pokúšalo eliminovat' rýchly nástup fašistickej krajnej pravice. ${ }^{84}$

Tento trend ešte výraznejšie pokračoval počas druhej svetovej vojny, ale úplne nebol nikdy dokončený. Vládna strana, nezávisle od toho pod akým menom pracovala (počas vojny sa už nazývala Stranou mad'arského života), bola totiž vždy pod vel'kým vplyvom verejnej správy, ktorú riadil premiér a minister vnútra. V tomto sa mad’arský stranícky model zásadne líšil od československého a čiastočne aj pôvodného rakúskeho modelu. Najviac presahov tu bolo s pol'ským pokusom vytvorit' vel'ký provládny blok. Paradoxne práve spomínaný vplyv konzervatívnej verejnej správy a postupne vznikajúceho antifašistického spojenectva medzi konzervatívcami okolo grófa Bethlena, starými legitimistami presadzujúcimi návrat Habsburgovcov, sociálnymi demokratmi a demokratickými malorol'níkmi spomal'oval v Mad’arsku nástup krajnej pravice.

Medzi spomínanými silami vzniklo vol'né spojenectvo brániace tzv. historickú ústavnost' pred pokusmi ju zmenit' na fašistickom základe. V tomto boji sa využívalo odvolávanie sa na národné tradície, ako aj na Svätú korunu. Tá však bola ako historický pojem dostatočne flexibilná na to, aby jej tradíciu dokázali na jeseň 1944 využit' aj pronemeckí krajní pravičiari zo strany šípových krížov „vodcu národa” Ferenca Szállasiho. Nakoniec

\footnotetext{
82 Tamže, s. 17-18.

83 Tamže, s. 23-24.

84 Tamže.
} 
teda hore spomínané spojenectvo nezabránilo nástupu fašizmu a celý proces vyvrcholil v tragédii roku 1944. Vtedy však bola situácia tragická v celom regióne.

Zložité medzivojnové obdobie neprebehlo vo všetkých krajinách strednej Európy podl’a jednotného scenára. Medzi jednotlivými skúmanými krajinami existovali vel'ké rozdiely, ktoré vyplývali jednak z odlišnej sociálno-ekonomickej východiskovej politiky a jednak z postavenia medzi vít’azmi alebo porazenými prvej svetovej vojny. Prirodzene išlo skôr o subjektívne pocity elít a širokých vrstiev, než o objektívny proces. Dokonca aj v rámci spomínaných dvoch skupín existovali rozdiely - o tom svedčí prípad Československa a Pol'ska, resp. Rakúska a Mad’arska, ktoré mali úplne odlišný postoj k svojej štátnej a právnej identite. Na druhej strane treba byt' opatrným s príliš ideologickými prístupmi pri analýze jednotlivých režimov. Myšlienky republikanizmu a demokracie boli totiž všade pomerne nové, staré politické a kultúrne tradície zase silné. Na jednej strane reálne nové trendy s ich dobrými aj zlými stránkami podstatne radikálnejšie zasiahli oficiálne konzervatívne Mad'arsko, než sa zväčša myslí. Na druhej strane v prospech stabilizácie československej demokracie pôsobili aj také tendencie, ktoré by sa dnes nepovažovali za príliš pozitívne. Taktiež v prípade ostatných krajín by sa dali nájst' rozličné zaujímavosti. Najlepšie je preto pravdepodobne neskúmat' len celkové trendy, ale aj vývoj každej krajiny a jej politického systému osobitne, pri podrobnom zohl'adnení miestnych špecifík. 